Article

\title{
In Vitro Antioxidant Activity of Litsea martabanica Root Extract and Its Hepatoprotective Effect on Chlorpyrifos-Induced Toxicity in Rats
}

\author{
Phraepakaporn Kunnaja ${ }^{1}$ D , Sunee Chansakaow ${ }^{2}$, Absorn Wittayapraparat ${ }^{3}$, Pedcharada Yusuk ${ }^{3}$ and \\ Seewaboon Sireeratawong $4, * \mathbb{D}$
}

check for updates

Citation: Kunnaja, P.; Chansakaow, S.; Wittayapraparat, A.; Yusuk, P.; Sireeratawong, S. In Vitro Antioxidant Activity of Litsea martabanica Root Extract and Its Hepatoprotective Effect on Chlorpyrifos-Induced Toxicity in Rats. Molecules 2021, 26, 1906. https://doi.org/10.3390/ molecules26071906

Academic Editor: Roberto Fabiani

Received: 25 February 2021

Accepted: 25 March 2021

Published: 28 March 2021

Publisher's Note: MDPI stays neutral with regard to jurisdictional claims in published maps and institutional affiliations.

Copyright: (c) 2021 by the authors. Licensee MDPI, Basel, Switzerland. This article is an open access article distributed under the terms and conditions of the Creative Commons Attribution (CC BY) license (https:/ / creativecommons.org/licenses/by/ $4.0 /)$.
1 Department of Medical Technology, Faculty of Associated Medical Sciences, Chiang Mai University, Chiang Mai 50200, Thailand; phraepakaporn.k@cmu.ac.th

2 Department of Pharmaceutical Sciences, Faculty of Pharmacy, Chiang Mai University, Chiang Mai 50200, Thailand; sunee.c@cmu.ac.th

3 Highland Research and Development Institute (Public Organization), Chiang Mai 50200, Thailand; absornw@hrdi.or.th (A.W.); npedcharada@hrdi.or.th (P.Y.)

4 Department of Pharmacology, Faculty of Medicine, Chiang Mai University, Chiang Mai 50200, Thailand

* Correspondence: seewaboon.s@cmu.ac.th; Tel.: +66-53-935351-3

\begin{abstract}
In Thailand, people in the highland communities whose occupational exposure to pesticides used the root of Litsea martabanica as a detoxifying agent. However, the scientific data to support the traditional use of this plant are insufficient. This study aimed to evaluate the antioxidant activity and anti-pesticide potential of L. martabanica root extract. Antioxidant properties were investigated by 2,2'-diphenyl-1-picrylhydrazyl (DPPH) assay, superoxide radicals scavenging assay, 2,2'-azino-bis(3ethylbenzothiazoline-6-sulfonic acid) (ABTS) assay, ferric reducing antioxidant power (FRAP), and total phenolic content determination. In all assays, L. martabanica extracts and their fractions exhibited high antioxidant activities differently. The water extract is traditionally used as a detoxifying agent. Therefore, it was chosen for in vivo experiments. The rats received the extract in a way that mimics the traditional methods of tribal communities followed by chlorpyrifos for 16 days. The results showed that acetylcholinesterase activity decreases in pesticide-exposed rats. Treatment with the extract caused increasing acetylcholinesterase activity in the rats. Therefore, L. martabanica extract may potentially be used as a detoxifying agent, especially for the chlorpyrifos pesticide. The antioxidant properties of L. martabanica may provide a beneficial effect by protecting liver cells from damage caused by free radicals. Histopathology results revealed no liver cell necrosis and showed the regeneration of liver cells in the treatment group. L. martabanica extract did not cause changes in behavior, liver weight, hematological and biochemical profiles of the rats.
\end{abstract}

Keywords: L. martabanica; antioxidant; anti-pesticide; medicinal plant; acetylcholinesterase activity; hepatoprotective

\section{Introduction}

Litsea is evergreen or a rare deciduous, dioecious tree or shrub in the family Lauraceae. There are over 400 species, mainly in tropical and subtropical Asia, but with a few species in the islands of the Pacific, Australia, and North and Central America, and 27 species in Thailand [1,2]. The plant in Litsea species has been used as traditional herbal medicines for thousands of years [3]. Twenty plants of the genus Litsea are found to be important traditional medicines in China for treating diarrhea, stomachache, dyspepsia, gastroenteritis, diabetes, edema, cold, arthritis, asthma, pain, traumatic injury, etc. [4]. One of the Litsea plants, Litsea cubeba, different parts of this plant, such as bark, leaf, root, and fruits, are used for treating many kinds of diseases [2]. This plant also exhibited antimicrobial, antioxidant, anti-cancer, anti-inflammatory, anti-diabetic, anti-insecticidal, and hepatoprotective activities [2]. 
Litsea martabanica (Kurz) Hook.f. is one of the species found in Thailand and is also distributed in China and Myanmar (Figure 1) [1]. The history of utilization of this plant is based on the wisdom of the highland communities. Various parts, i.e., the roots, leaves, and stems, have been traditionally used as medicine in the highland area of the northern part of Thailand for curing kidney disease, curing toxic allergy symptoms, and detoxification [5]. Detoxification or removal of toxins in humankind is an alternative way to promote good health for the people in the highland area who use pesticides and insecticides in daily life. The accumulation of pesticides in the body may be through the consumption of contaminated food or exposure in the occupational environment [6]. Organophosphate and carbamate are commonly used pesticides due to a short half-life and are non-persistent in the environment [7]. These pesticides cause acetylcholinesterase (AChE) enzyme inhibition, leading to an increase of acetylcholine (ACh) at the synapses and neuromuscular junctions. Organophosphates (OPs) are irreversible AChE inhibitors [8]. AChE inhibition causes muscarinic and nicotinic toxicity, including cramps, increased salivation, lacrimation, muscular weakness, paralysis, muscular fasciculation, diarrhea, and blurred vision [9]. It has been reported that OP pesticides induced reactive oxygen species (ROS) generation, which alters an antioxidant system leading oxidative damage to the cells [10]. Humans with occupational exposes to the pesticide have been reported to have increased lipid peroxidation and significantly reduced AChE activity $[11,12]$. The levels of antioxidant enzymes, catalase, superoxide dismutase, glutathione peroxidase, and glutathione reductase, as well as non-enzymatic antioxidant, reduced glutathione, were changed in organophosphate poisoning $[13,14]$. Prolonged exposure to these pesticides was reported to be associated with various types of cancers [15] and pathologic liver diseases such as hepatitis, fibrosis, and cirrhosis [16,17].

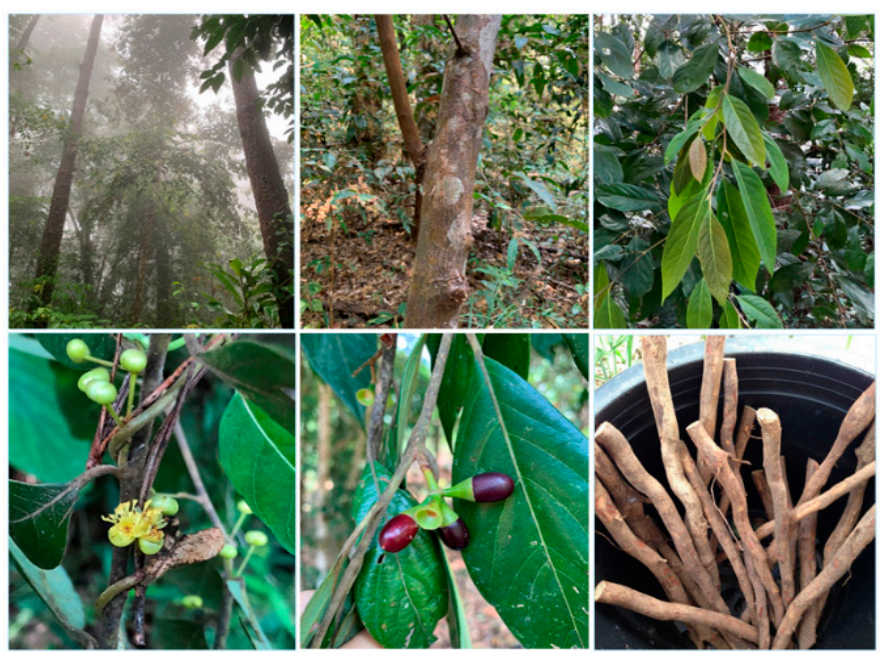

Figure 1. Litsea martabanica (Kurz) Hook.f.

The liver is the first organ to eliminate potentially harmful xenobiotics and pesticides through the cytochrome P450 enzyme metabolism. However, a high dose of pesticide exposure may reduce the detoxifying function of the liver, leading to liver cell injury. The pesticide-induced liver toxicity involves ROS generation, which causes oxidative damage to the liver cells. Some reports suggested that antioxidant substances may be beneficial in the treatment of acute organophosphate pesticide poisoning $[18,19]$. The generation of oxygen-free radicals during pesticide exposure can be neutralized by various enzymatic and non-enzymatic antioxidant systems [20,21]. Plants are considered as an important source to meliorate ROS. The non-enzymatic antioxidants, including ascorbic acid, glutathione, proline, carotenoids, phenolic acids, flavonoids, tannins, etc., were found in many plants [22]. Some research findings purposed the potential use of many non-enzymatic antioxidant substances to eliminate the adverse effect of pesticides [23]. An in vitro experi- 
mental study has reported that vitamin C and vitamin E may ameliorate oxidative stress induced by organophosphate pesticides through the decreasing of lipid peroxidation in erythrocytes $[24,25]$. A study in Wistar rats has demonstrated that vitamin C pretreatment improves sensorimotor and cognitive functions in acute short-term chlorpyrifos-exposed rats [26].

Besides indigenous knowledge, there are no scientific data, especially pharmacological activities, to support the traditional use of L. martabanica as a detoxifying agent. In the present study, we investigated the anti-pesticide potential of L. martabanica extract on rats. AChE activity, which represents pesticide exposure, was measured in the rats' blood samples. Other parameters, including body weight change, blood hematology, blood chemistry profiles, and internal organ weight, were determined. Many plants in the Litsea species have been reported to possess high antioxidant activity [2,3]. Therefore, we investigated the in vitro antioxidant activity of $L$. martabanica extract as well.

\section{Results}

\subsection{Microscopic Character and Chemical Pattern of the Extract of L. martabanica}

The raw material of L. martabanica (root) was extracted by decoction, following indigenous methods using water as a solvent. The extract was filtrated, concentrated until $\%$ Brix $=3$, added pharmaceutical aids adsorbent $\left(\mathrm{Cab}-\mathrm{O}-\mathrm{Sil}^{\circledR}\right)$ as a carrier, and then dried by a spray dryer. The obtained brownish powder was $5.38 \% w / w$. Microscopic characteristics were analyzed by microscope connect with camera-lucida (Figure 2). Starch grains, fibers, epidermis, fibers containing starch grains, bordered vessels, and stone cells are major tissues found in the powder of the root of L. martabanica. The microscopic characteristics can be used for identification because the identity tissue is revealed in each different plant. The monograph of the root of L. martabanica has not been officially found in any pharmacopeia or textbooks. As a result, the specification of the root of this plant can be used as a reference for the quality control of raw materials in a further study.

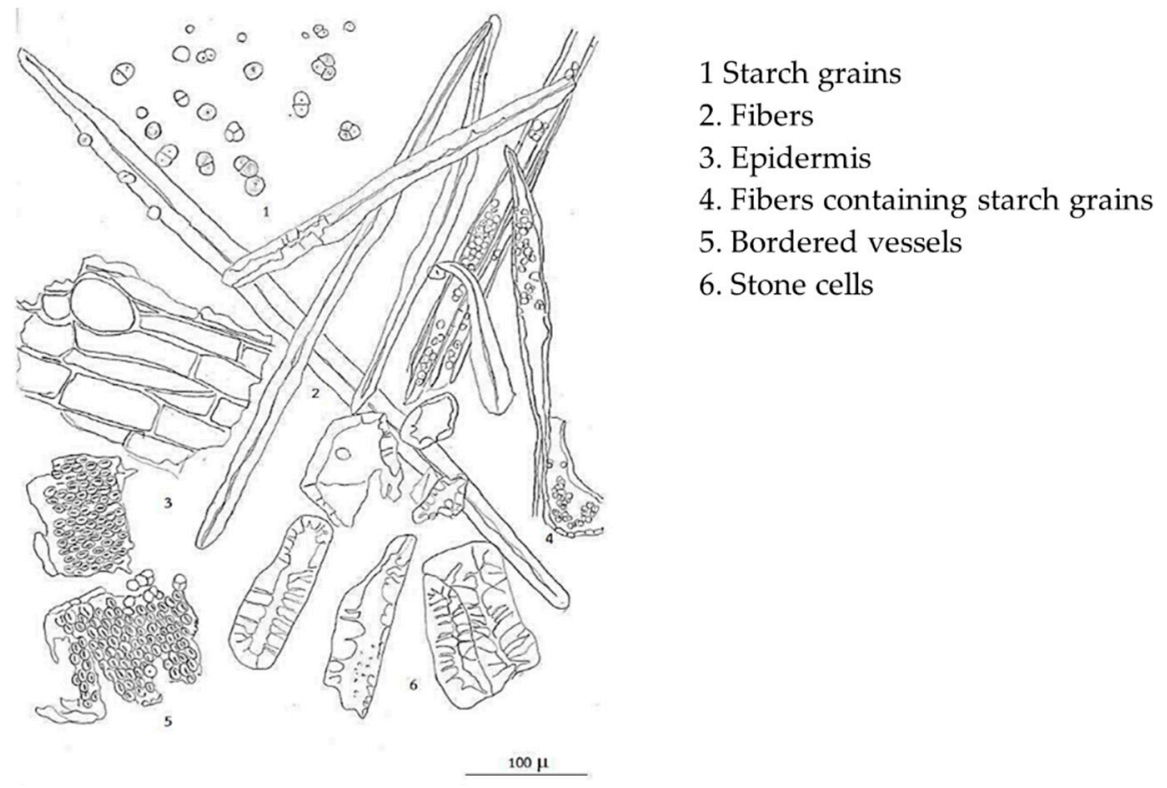

Figure 2. Microscopic character of powder of L. martabanica (root).

Phytochemical screening was carried out for the root of L. martabanica, as described in the standard method [27]. The phenolics, flavonoids, and terpenes were found in the test sample. The results of the evaluation of their quality following the methods described in the Thai herbal pharmacopeia 2018 [27] are shown in Table 1. 
Table 1. Physical and chemical properties of root of L. martabanica.

\begin{tabular}{cc}
\hline Test & Result \\
\hline Foreign matter $(\% w / w)$ & Not found \\
Ethanol extractive content $(\% w / w)$ & $33.0534 \pm 0.06$ \\
Water extractive content $(\% w / w)$ & $24.1200 \pm 0.04$ \\
Loss on drying $(\% v / w)$ & $9.6867 \pm 0.02$ \\
Total ash $(\% w / w)$ & $1.4645 \pm 0.01$ \\
Acid-insoluble ash $(\% w / w)$ & $0.1578 \pm 0.00$ \\
Chemical composition & phenolics, flavonoids, terpenes \\
\hline
\end{tabular}

Values are expressed as mean \pm standard error of the mean (S.E.M.) from three independence experiments.

The chemical profile was performed with the suitable mobile phase, compared with known bioactive compounds, and visualized under UV $254 \mathrm{~nm}$ and $366 \mathrm{~nm}$. The densitogram of the water extract and ethanolic extract indicated 3 and 7 major bands, respectively (Figure 3A,B and Figure 4). The ethanolic extract and water extract of the root of L. martabanica did not consist of apigenin, caffeic acid, gallic acid, kaemferol, pinene, and quercetin compared to the standard rate of flow (Rf) value. The fractions isolated by the different solvent polarities found that the chloroform fraction and aqueous alcoholic fraction revealed the same component at Rf $0.17,0.25$, and 0.38 . Therefore, it may be that the bioactive compound(s) found in this plant is partly used. The phytochemical components of this plant have not been reported. Therefore, bioassay-guided isolation will need to be studied further to find bioactive compounds. In this study, the high-performance thin-layer chromatography or HPTLC chromatogram did not indicate the chemical components, but fingerprinting can be used to analyze the quantification of phytochemical herbal products, and examine adulteration in herbal formulations.

A



B

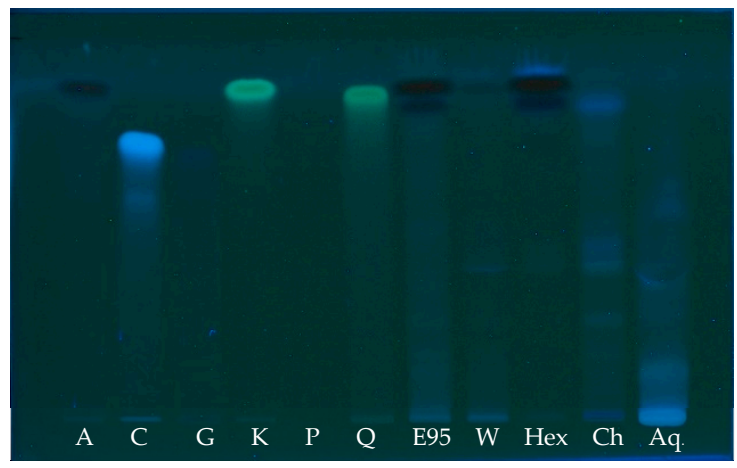

Figure 3. The high-performance thin-layer chromatography (HPTLC) chromatogram (A) at $254 \mathrm{~nm} ;(\mathbf{B})$ at $366 \mathrm{~nm}$. A = apigenin; $\mathrm{C}=$ caffeic acid; $\mathrm{G}=$ gallic acid; $\mathrm{K}=$ kaemferol; $\mathrm{P}=$ pinene; $\mathrm{Q}=$ quercetin; $\mathrm{E}=$ ethanolic crude extract; $\mathrm{W}=$ water crude extract; $\mathrm{Hex}=\mathrm{n}$-hexane fraction; $\mathrm{Ch}=$ chloroform fraction; and $\mathrm{Aq}=$ aqueous alcohol fraction. 




Figure 4. HPTLC Chromatogram at $254 \mathrm{~nm}$. $\mathrm{A}=$ apigenin; $\mathrm{C}=$ caffeic acid; $\mathrm{G}=$ gallic acid; $\mathrm{K}=$ kaemferol; $\mathrm{P}=$ pinene; $\mathrm{Q}$ = quercetin; $\mathrm{E}$ = ethanolic crude extract; $\mathrm{W}=$ water crude extract; $\mathrm{Hex}=\mathrm{n}$-hexane fraction; $\mathrm{Ch}=$ chloroform fraction; and $\mathrm{Aq}=$ aqueous alcohol fraction. $\mathrm{Rf}$, rate of flow; $\mathrm{AU}, \mathrm{ab}-$ sorbance units.

\subsection{2,2'-diphenyl-1-picrylhydrazyl (DPPH) Scavenging Activity}

L. martabanica fractions inhibited DPPH free radicals in a concentration-dependent manner, as shown in Figure 5. The reference standard gallic acid had the highest efficacy in scavenged DPPH free radicals. The result of the half maximal inhibitory concentration $\left(\mathrm{IC}_{50}\right)$ values is shown in Table 2. Among these fractions, aqueous ethanol fraction, crude water extract, and crude ethanol extract exhibited higher antioxidant properties than chloroform and hexane fraction.

\subsection{Superoxide Radical Scavenging Activity}

In this assay, the extracts and fractions of L. martabanica inhibited superoxide radical generation in a concentration-dependent manner (Figure 6). Free radical scavenging efficacy of different test samples and gallic acid was in the following order: gallic acid $>$ aqueous ethanol fraction $>$ crude water extract $>$ crude ethanol extract $>\mathrm{CHCl}_{3}$ fraction $>$ hexane fraction.

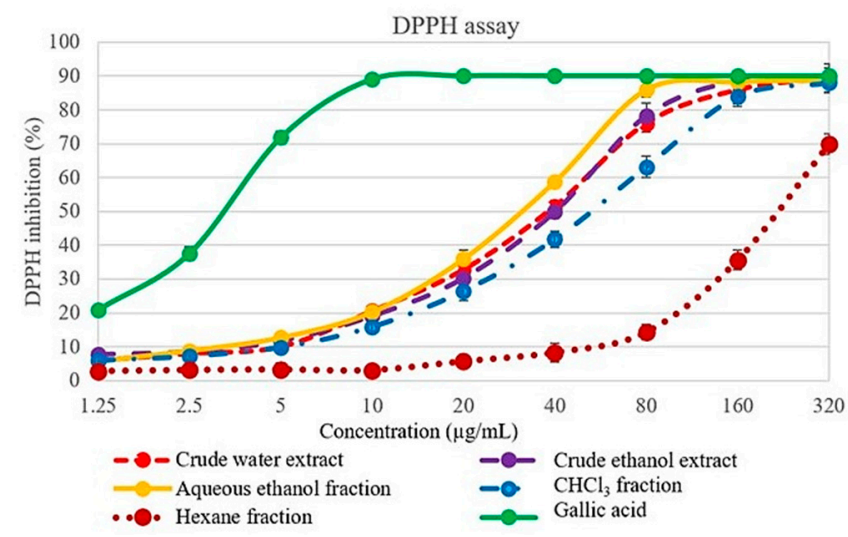

Figure 5. Effect of L. martabanica fractions on 2,2'-diphenyl-1-picrylhydrazyl (DPPH) free radicals scavenging. Values are expressed as mean \pm S.E.M. from three independent experiments. 


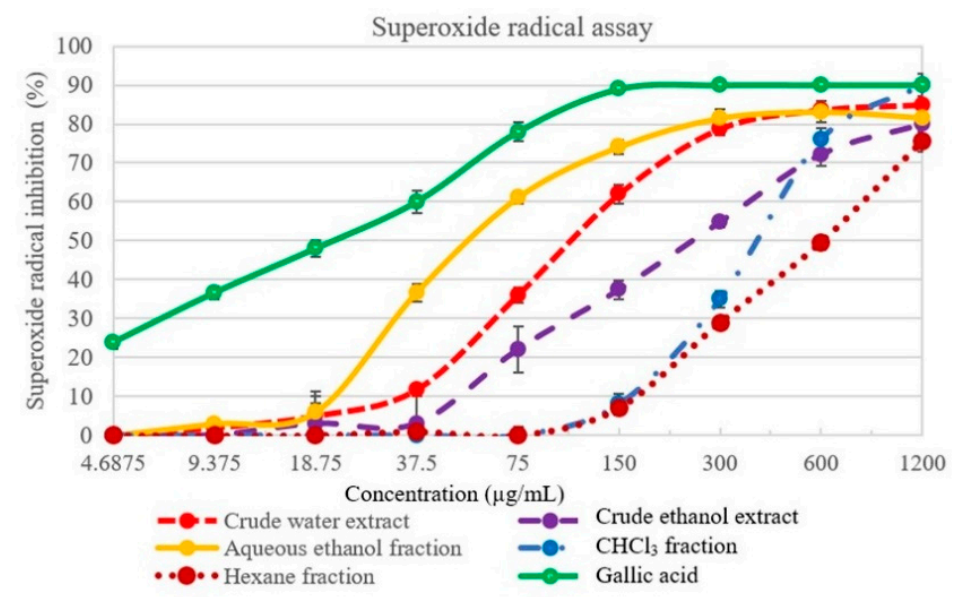

Figure 6. Effect of L. martabanica fractions on superoxide radical scavenging. Values are expressed as mean \pm S.E.M. from three independent experiments.

Table 2. The $\mathrm{IC}_{50}$ values of L. martabanica root extracts in DPPH assay and superoxide radical assay.

\begin{tabular}{ccc}
\hline \multirow{2}{*}{ Test Samples } & \multicolumn{2}{c}{$\mathrm{IC}_{\mathbf{5 0}}(\boldsymbol{\mu g} / \mathbf{m L})$} \\
\cline { 2 - 3 } & DPPH & Superoxide Radical Scavenging \\
\hline Gallic acid & $2.7 \pm 0.01$ & $23.8 \pm 3.9$ \\
Crude water extract & $42.8 \pm 4.1$ & $118.6 \pm 10.4$ \\
Crude ethanol extract & $44.2 \pm 2.3$ & $259.3 \pm 28.9$ \\
Hexane fraction & $233.8 \pm 21.7$ & $593.5 \pm 9.7$ \\
CHCl $_{3}$ fraction & $57.0 \pm 1.6$ & $417.7 \pm 10.1$ \\
Aqueous ethanol fraction & $32.4 \pm 1.5$ & $58.9 \pm 5.2$ \\
\hline
\end{tabular}

Values are expressed as mean \pm S.E.M. from three independent experiments. $\mathrm{IC}_{50}$, the half maximal inhibitory concentration; DPPH, 2,2'-diphenyl-1-picrylhydrazyl.

\subsection{2,2'-Azino-Bis-(3-Ethylbenzothiazoline-6-Sulfonic Acid) (ABTS) Radical Scavenging Activity}

The ability of an extract to scavenge the ABTS radical is shown in Table 3 . The crude ethanol extract possesses the most superior ability to scavenge free radicals as compared to other fractions. Radical scavenging efficacy in this assay was in the following order: crude ethanol extract $>\mathrm{CHCl}_{3}$ fraction $>$ hexane fraction $>$ crude water extract $>$ aqueous ethanol fraction.

\subsection{Ferric Reducing Antioxidant Power (FRAP)}

As shown in Table 3, the $\mathrm{CHCl}_{3}$ fraction and crude ethanol extract of L. martabanica showed a greater FRAP value than other test samples. The FRAP values were $1554.1 \mathrm{mM}$ and $1376.2 \mathrm{mM}$ Fe (II)/g extract, respectively. The other test samples, aqueous ethanol fraction, crude water extract, and hexane fraction, showed FRAP values of $418.6 \mathrm{mM}$, $368.9 \mathrm{mM}$, and $275.4 \mathrm{mM} \mathrm{Fe}$ (II)/g extract, respectively.

\subsection{Total Phenolic Content (TPC)}

The amount of total phenolics varied widely in L. martabanica extracts and their fractions from 39.3 to $173.1 \mathrm{mg}$ gallic acid equivalent (GAE)/g dry extract (Table 3). Among the test samples, the $\mathrm{CHCl}_{3}$ fraction displayed the highest amount of total phenolics. The phenolic content was found to be in the order of the $\mathrm{CHCl}_{3}$ fraction > crude ethanol extract $>$ hexane fraction $>$ crude water extract $>$ aqueous ethanol fraction. 
Table 3. Antioxidant properties of L. martabanica root extracts in ABTS assay, FRAP assay, and TPC assay.

\begin{tabular}{cccc}
\hline \multirow{2}{*}{ Test Samples } & ABTS & FRAP & TPC \\
\cline { 2 - 4 } & (TE mg/g Extract) & (mM Fe (II)/g Extract) & GAE (mg/g Extract) \\
\hline Crude water extract & $78.2 \pm 1.4$ & $368.9 \pm 23.4$ & $42.2 \pm 4.5$ \\
Crude ethanol extract & $188.0 \pm 0.9$ & $1376.2 \pm 60.4$ & $147.9 \pm 2.8$ \\
Hexane fraction & $98.8 \pm 10.9$ & $275.4 \pm 39.5$ & $56.5 \pm 4.9$ \\
CHCl $_{3}$ fraction & $163.4 \pm 8.8$ & $1554.1 \pm 23.9$ & $173.1 \pm 0.4$ \\
Aqueous ethanol fraction & $71.1 \pm 10.6$ & $418.6 \pm 31.0$ & $39.3 \pm 5.1$ \\
\hline
\end{tabular}

Values are expressed as mean \pm S.E.M. from three independent experiments. ABTS, 2,2'-azino-bis-(3-ethylbenzothiazoline-6-sulfonic acid); FRAP, ferric reducing antioxidant power; TPC, total phenolic content; TE, trolox equivalent; GAE, gallic acid equivalent.

The observed results from antioxidant assays demonstrated that chloroform fraction possesses high antioxidant property over the other fraction, followed by crude ethanol extract, aqueous ethanol fraction, water extract, and hexane fraction, respectively. However, the crude water extract is traditionally used as a detoxifying agent by local people in the highland communities. Therefore, the water extract of L. martabanica was typically chosen for in vivo experiments.

\subsection{Anti-Pesticide Potential}

The result of the AChE activity is shown in Figure 7. AChE activity of the control rats received chlorpyrifos significantly decrease from the normal rats. However, co-treatment of L. martabanica and chlorpyrifos tended to increase AChE activity. The high efficacy of the extract in increasing AChE activity was seen in the high doses of the extract at 750 and $250 \mathrm{mg} / \mathrm{kg}$. AChE activity significantly increased when compared with control rats. Thus, this extract may have the potential to reverse organophosphate poisoning.

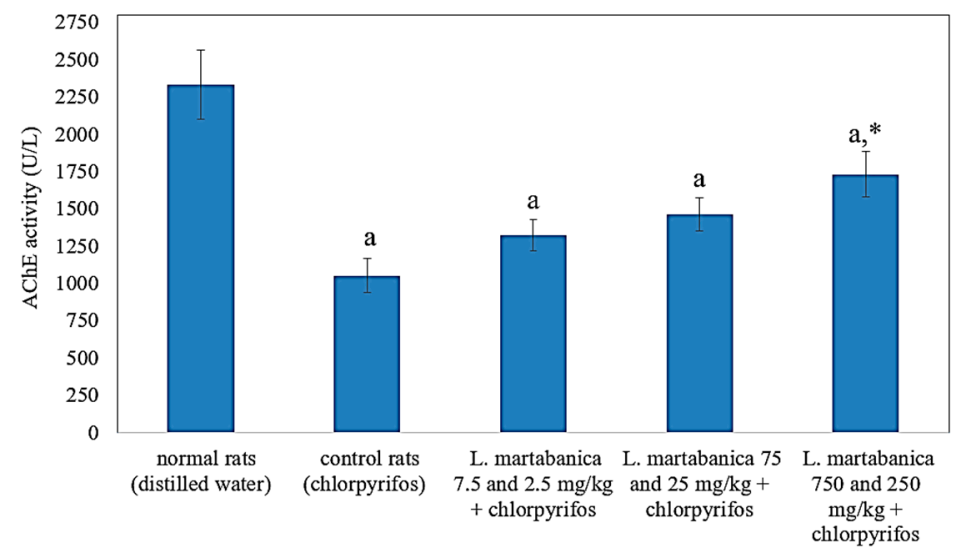

Figure 7. Effect of L. martabanica water extract on AChE activity. Values are expressed as mean \pm S.E.M. ${ }^{a}$ Significantly different from the normal rats, $p<0.05$. ${ }^{*}$ Significantly different from the control rats, $p<0.05$, according to one-way ANOVA.

\subsection{Observation of Behavioral Change and Toxicological Signs}

The rats in the control group showed signs of toxicity such as piloerection, irregular respiratory patterns, and isolation from the group. L. martabanica extract treatment rats did not show any signs of toxicity and revealed behavior similar to the rats in the normal groups.

\subsection{Body Weight Change, Organs Weight, and Histological Examination Results}

On day 16, the bodyweight of the control rats and L. martabanica-treated rats significantly decreased compared with the normal rats (Figure 8). Gross pathological examination revealed normal internal organs in all rats. The liver weight of extract-treated rats did not differ from control rats, except for the liver weight of rats that received the L. martabanica 
extract at doses of 75 and $25 \mathrm{mg} / \mathrm{kg}$ (Table 4). However, the liver weight of all extract treatment groups did not differ from the normal rats.

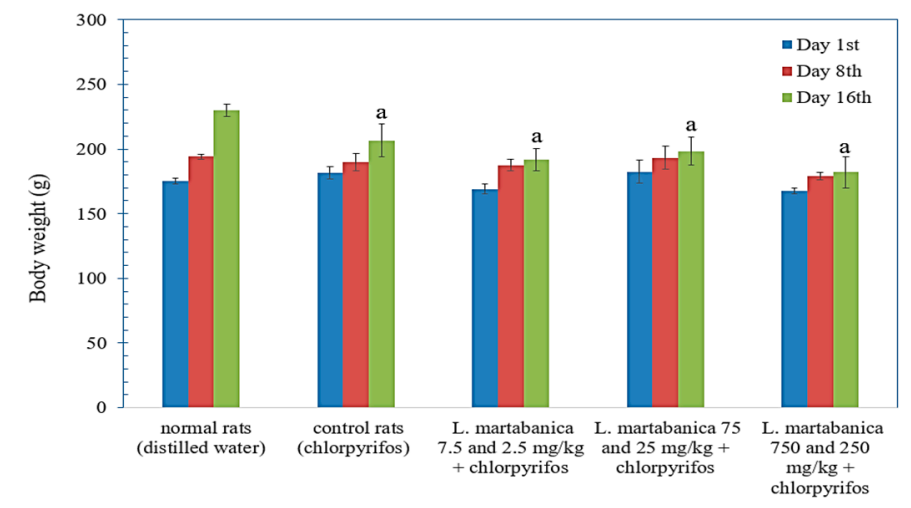

Figure 8. The effect of L. martabanica water extract on the body weight of rats. Values are expressed

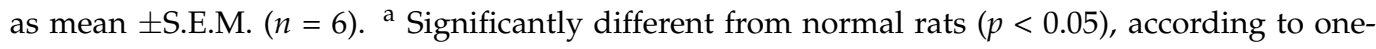
way ANOVA.

Table 4. Effect of L. martabanica water extract on the liver weight of rats.

\begin{tabular}{cc}
\hline Group & Liver Weight $(\mathbf{g})$ \\
\hline Normal rats & $10.7 \pm 0.58$ \\
Control rats (chlorpyrifos) & $11.89 \pm 0.65$ \\
L. martabanica extract + chlopyrifos & \\
7.5 and $2.5 \mathrm{mg} / \mathrm{kg}$ & $12.37 \pm 0.96$ \\
75 and $25 \mathrm{mg} / \mathrm{kg}$ & $9.47 \pm 0.90^{*}$ \\
750 and $250 \mathrm{mg} / \mathrm{kg}$ & $11.21 \pm 0.70$ \\
\hline
\end{tabular}

Values are expressed as mean \pm S.E.M. $(n=6) .{ }^{*}$ Significantly different from control rats $(p<0.05)$.

The results of liver pathology are shown in Figure 9. In the control group, the sinusoids are dilated or widen in comparison to the normal group. The scattered foci of hepatic necrosis in zone 2 were observed. No centrilobular necrosis is usually associated with congestion in this group. The liver histology of the L. martabanica-treated group is not comparable to the normal group, since the sinusoids are widened. However, no hepatic necrosis is noted. The cells are varied in shapes and sizes but their nuclei are vesicles with small nuclei.

\subsection{Hematology Analysis}

As shown in Table 5, the hematological parameters such as mean corpuscular volume $(\mathrm{MCV})$, mean corpuscular hemoglobin $(\mathrm{MCH})$, mean corpuscular hemoglobin concentration (MCHC), and platelet (PLT) significantly increased in the control rats. Red blood cell (RBC), hemoglobin (HBG), and hematocrit (HCT) tended to decrease, but no statistical difference was observed. L. martabanica extract treatment could alter RBC, HBG, HCT, MCV, $\mathrm{MCH}, \mathrm{MCHC}$, and PLT parameters close to the normal rats. Neutrophils and lymphocytes significantly decreased at high doses of treatment. However, at medium doses, these values did not differ from the normal rats. These effects may result from the biological variation among the rats. All hematological parameters were in the normal reference range for rats [28].

\subsection{Blood Chemistry Analysis}

The results of blood chemistry profiles are presented in Table 6 . The markers of kidney function blood urea nitrogen (BUN) and creatinine $(\mathrm{Cr})$ levels tended to increase in the control group, but did not show a statistically significant difference. The rats treated with L. martabanica at doses of 7.5 and $2.5 \mathrm{mg} / \mathrm{kg}$ showed significantly decreased BUN and Cr 
levels compared with control rats. The blood chemistry values total protein (TP), albumin (ALB), total bilirubin (TB), direct bilirubin (DB), aspartate aminotransferase (AST), alanine aminotransferase (ALT), and alkaline phosphatase (ALP) typically represent liver function. These values significantly increased in control rats. However, L. martabanica treatment could shift abnormal parameters close to the normal rats [28].

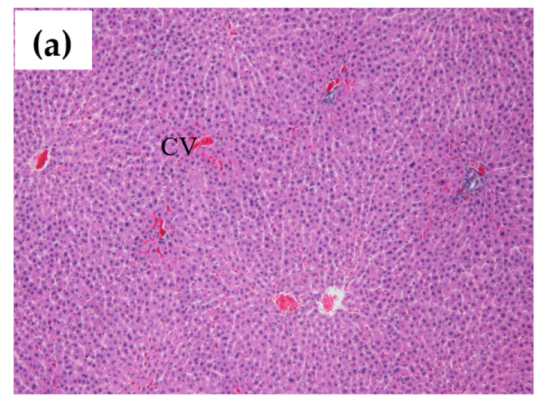

Normal liver tissues with the central vein and portal tract in normal group ( $4 \times$ magnification)

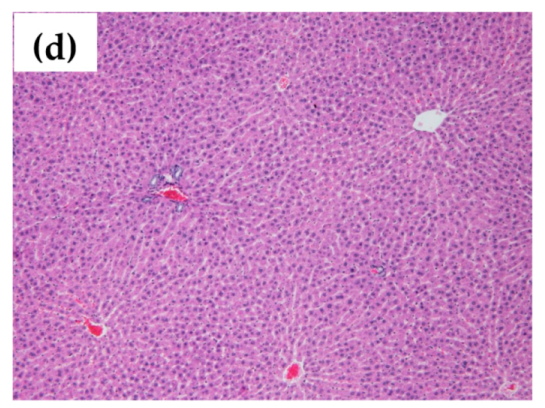

Abnormal liver tissues with the central vein and portal tract of pesticide-treated rats in the control group (4× magnification).

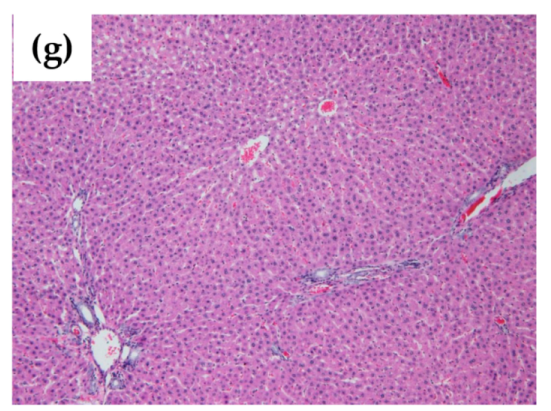

The liver tissues with the central vein and portal tract of $L$.martabanica extracttreated group ( $4 \times$ magnification).



Normal central vein (CV) (10× magnification)

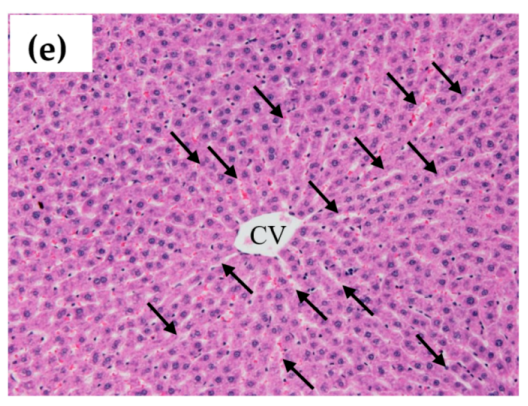

The arrow show the increasing number of sinusoids dilation in the control group (10× magnification).

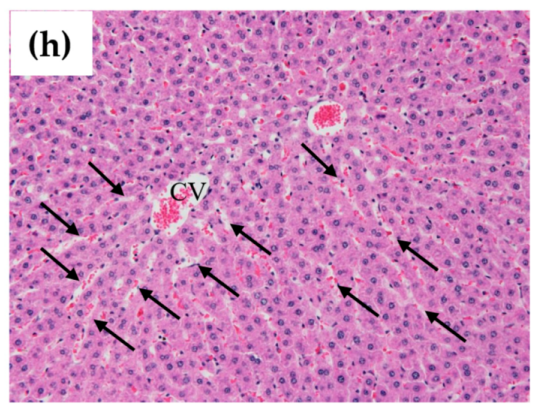

The arrow show the decreasing number of sinusoids dilation in the $L$. martabanica extract-treated group (10× magnification).

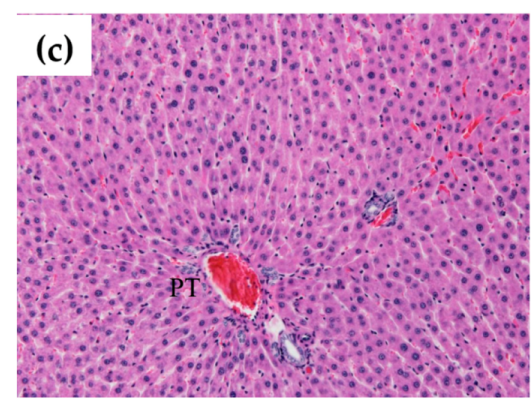

Normal portal tract (PT) (10× magnification)



The circle show the scattered foci of hepatic necrosis in zone 2 in the control group (10× magnification).

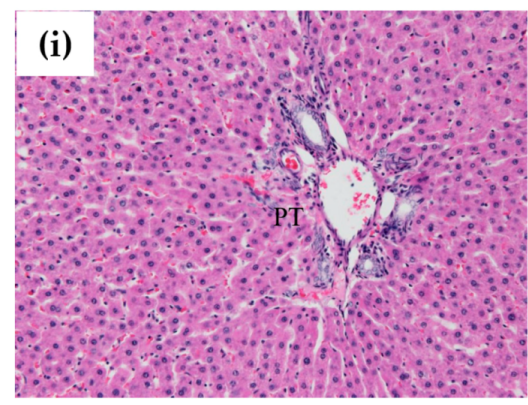

Hepatic necrosis is absent in $L$. martabanica extract-treated group. The regeneration of hepatic cells is found in zone $2(10 \times$ magnification).

Figure 9. Histopathologic results of rat liver. $(\mathbf{a}-\mathbf{c})$ : Histology results of the normal rat liver in the normal group. (d-f): Histology results of the rat liver in the control group receiving chlorpyrifos. The picture shows the dilation of sinusoids (arrow) and the scattered foci of hepatic necrosis in zone 2 (circle). (g-i): Histology results of the group that received high doses of L. martabanica extract (750 and $250 \mathrm{mg} / \mathrm{kg}$ ). The number of sinusoids dilation is decreased. 
Table 5. Effect of L. martabanica water extract on the hematological values of rats.

\begin{tabular}{|c|c|c|c|c|c|}
\hline \multirow{2}{*}{ Parameters } & \multirow{2}{*}{ Normal Rats } & \multirow{2}{*}{ Control Rats } & \multicolumn{3}{|c|}{ L. martabanica. Water Extract (mg/kg) } \\
\hline & & & 7.5 and 2.5 & 75 and 25 & 750 and 250 \\
\hline $\mathrm{RBC}\left(\times 10^{6} / \mu \mathrm{L}\right)$ & $7.0 \pm 0.13$ & $5.8 \pm 0.80$ & $7.5 \pm 2.45$ & $7.0 \pm 0.22$ & $6.9 \pm 0.23$ \\
\hline HGB (g/dL) & $13.6 \pm 0.22$ & $12.5 \pm 0.41$ & $11.5 \pm 1.02$ & $13.7 \pm 0.41$ & $13.4 \pm 0.43$ \\
\hline $\mathrm{HCT}(\%)$ & $41.3 \pm 0.87$ & $36.5 \pm 3.88$ & $38.6 \pm 0.64$ & $41.7 \pm 1.62$ & $41.3 \pm 1.20$ \\
\hline MCV (fL) & $59.4 \pm 0.28$ & $64.3 \pm 2.92^{\mathrm{a}}$ & $59.2 \pm 0.44 *$ & $59.2 \pm 0.56^{*}$ & $59.2 \pm 0.43 *$ \\
\hline $\mathrm{MCH}(\mathrm{pg})$ & $19.6 \pm 0.12$ & $25.8 \pm 4.20^{\mathrm{a}}$ & $19.3 \pm 0.13^{*}$ & $19.5 \pm 0.11 *$ & $19.2 \pm 0.18^{*}$ \\
\hline $\mathrm{MCHC}(\mathrm{g} / \mathrm{dL})$ & $33.0 \pm 0.17$ & $39.2 \pm 4.38^{\mathrm{a}}$ & $32.7 \pm 0.22 *$ & $32.9 \pm 0.33 *$ & $32.4 \pm 0.19$ * \\
\hline $\operatorname{PLT}\left(\times 10^{5} / \mu \mathrm{L}\right)$ & $7.53 \pm 0.34$ & $8.78 \pm 1.04^{\mathrm{a}}$ & $6.76 \pm 0.14 *$ & $7.91 \pm 0.50$ & $7.25 \pm 0.19$ \\
\hline $\mathrm{WBC}\left(\times 10^{3}\right.$ cells $\left./ \mu \mathrm{L}\right)$ & $2.84 \pm 0.49$ & $2.87 \pm 0.72$ & $1.68 \pm 0.31^{\mathrm{a}, *}$ & $2.72 \pm 1.32$ & $2.18 \pm 0.37$ \\
\hline $\mathrm{Nu}($ cells $/ \mu \mathrm{L})$ & $0.39 \pm 0.06$ & $0.45 \pm 0.21$ & $0.30 \pm 0.06$ & $0.31 \pm 0.14$ & $0.16 \pm 0.05^{a, *}$ \\
\hline Lymph (cells/ $\mu \mathrm{L})$ & $2.26 \pm 0.38$ & $2.24 \pm 0.45$ & $3.00 \pm 1.92$ & $2.30 \pm 1.12$ & $0.97 \pm 0.30^{\mathrm{a}, *}$ \\
\hline Mono (cells $/ \mu \mathrm{L}$ ) & $0.15 \pm 0.04$ & $0.15 \pm 0.05$ & $0.09 \pm 0.02$ & $0.09 \pm 0.06$ & $0.05 \pm 0.02$ \\
\hline $\mathrm{E}(\mathrm{cells} / \mu \mathrm{L})$ & $0.00 \pm 0.01$ & $0.00 \pm 0.02$ & $0.00 \pm 0.00$ & $0.00 \pm 0.01$ & $0.00 \pm 0.00$ \\
\hline $\mathrm{Ba}($ cells $/ \mu \mathrm{L})$ & $0.00 \pm 0.00$ & $0.00 \pm 0.00$ & $0.00 \pm 0.00$ & $0.00 \pm 0.00$ & $0.00 \pm 0.00$ \\
\hline
\end{tabular}

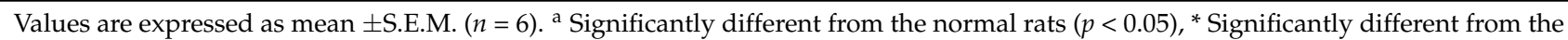
control rats (chlorpyrifos) $(p<0.05)$, according to one-way ANOVA. RBC, red blood cell; HGB, hemoglobin; HCT, hematocrit; MCV, mean corpuscular volume; $\mathrm{MCH}$, mean corpuscular hemoglobin; $\mathrm{MCHC}$, mean corpuscular hemoglobin concentration; PLT, platelet; WBC, white blood cell; Nu, neutrophil; Lymph, lymphocyte; Mono, monocyte; E, eosinophil; Ba, basophil.

Table 6. Effect of L. martabanica water extract on the blood chemistry values of rats.

\begin{tabular}{|c|c|c|c|c|c|}
\hline \multirow{2}{*}{ Parameters } & \multirow{2}{*}{ Normal Rats } & \multirow{2}{*}{ Control Rats } & \multicolumn{3}{|c|}{ L. martabanica. Water Extract (mg/kg) } \\
\hline & & & 7.5 and 2.5 & 75 and 25 & 750 and 250 \\
\hline BUN (mg/dL) & $18.4 \pm 0.74$ & $20.1 \pm 1.02$ & $15.6 \pm 0.91 *$ & $16.6 \pm 1.47$ & $19.9 \pm 2.38$ \\
\hline $\mathrm{Cr}(\mathrm{mg} / \mathrm{dL})$ & $0.66 \pm 0.01$ & $0.79 \pm 0.02$ & $0.67 \pm 0.01$ & $0.57 \pm 0.10 *$ & $0.72 \pm 0.04$ \\
\hline $\mathrm{TP}(\mathrm{g} / \mathrm{dL})$ & $5.9 \pm 0.07$ & $6.9 \pm 0.45^{\mathrm{a}}$ & $5.8 \pm 0.11 *$ & $6.1 \pm 0.23$ & $6.1 \pm 0.40$ \\
\hline $\operatorname{ALB}(g / d L)$ & $2.9 \pm 0.04$ & $3.4 \pm 0.24^{\mathrm{a}}$ & $2.9 \pm 0.02 *$ & $3.1 \pm 0.14$ & $3.0 \pm 0.19$ \\
\hline $\mathrm{TB}(\mathrm{mg} / \mathrm{dL})$ & $0.09 \pm 0.01$ & $0.16 \pm 0.03^{\mathrm{a}}$ & $0.10 \pm 0.01 *$ & $0.10 \pm 0.02 *$ & $0.08 \pm 0.02 *$ \\
\hline $\mathrm{DB}(\mathrm{mg} / \mathrm{dL})$ & $0.03 \pm 0.01$ & $0.09 \pm 0.01^{\mathrm{a}}$ & $0.03 \pm 0.00 *$ & $0.05 \pm 0.00 *$ & $0.04 \pm 0.01 *$ \\
\hline AST (U/L) & $85 \pm 5.57$ & $133 \pm 9.20^{\mathrm{a}}$ & $85 \pm 4.24 *$ & $92 \pm 9.16^{*}$ & $92 \pm 6.70 *$ \\
\hline $\operatorname{ALT}(\mathrm{U} / \mathrm{L})$ & $30 \pm 7.65$ & $57 \pm 5.26^{a}$ & $45 \pm 3.35$ * & $41 \pm 5.33$ * & $38 \pm 2.55^{*}$ \\
\hline $\operatorname{ALP}(\mathrm{U} / \mathrm{L})$ & $165 \pm 9.26$ & $214 \pm 19.69^{a}$ & $180 \pm 11.99 *$ & $137 \pm 10.46^{*}$ & $174 \pm 14.86$ * \\
\hline
\end{tabular}

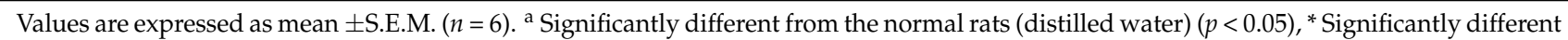
from the control rats (distilled water + chlorpyrifos), $(p<0.05)$. BUN, blood urea nitrogen; $\mathrm{Cr}$, creatinine; TP, total protein; ALB, albumin, TB, total bilirubin; DB, direct bilirubin; AST, aspartate aminotransferase; ALT, alanine aminotransferase; ALP, alkaline phosphatase.

\section{Discussion}

The root of L. martabanica was traditionally used for detoxification by the highland communities in Thailand. However, scientific data to support the traditional use of this plant are still insufficient. In the present study, we investigated the microscopic character of L. martabanica, as well as the chemical patterns, antioxidant activity, and anti-pesticide potential of L. martabanica root extract.

Antioxidants are essential substances to scavenge free radicals and prevent oxidative damage to the cells. The single antioxidant method is insufficient to study the antioxidant capacity of the plant samples. The measurement of antioxidant activity needs to use the various models to evaluate antioxidant mechanisms [29]. DPPH assay, superoxide radical assay, ABTS assay, FRAP assay, and total phenolic content are the methods used for screening the antioxidant activity of plant samples [30,31]. The results of all antioxidant assays indicated that L. martabanica root extract exhibited high antioxidant activities. Various plants in the genus Litsea provided a rich source of natural antioxidants to possess free radical scavenging potential [3]. L. martabanica extracts and their fractions demonstrated different antioxidant efficacy in each assay model. These results correlated with the previous scientific reports. For example, L. coreana var. lanuginose or Hawk primary leaf tea infusion (HPI) had high polyphenols contents and exhibited scavenging activity 
in DPPH and FRAP assay [32]. The methanol extract of L. cubeba showed remarkable antioxidant activity in DPPH assay, peroxidase/guaiacol assay, and thiobarbituric acid (TBA) test in comparison with $\alpha$-tocopherol and ascorbic acid [33]. The study of chemical constituents of 20 litsea plant species in China has been reported compose of flavonoids, terpenoids, alkaloids, butanolides and butenolactones, lignans, amides, steroids, fatty acids, and megastigmanes [4,34].

Flavonoids and terpenoids are important bioactive constituents in this genus and exert a therapeutic effect in preventing or slowing oxidative stress-related diseases [4]. Phenolic compounds are considered secondary metabolites synthesized by plants. These compounds play an essential role in multiple biological effects, including antioxidant activity by scavenging free radicals [35-38]. The results of chemical composition in this study showed the presence of phenolics, flavonoids, and terpenes in the root of L. martabanica. The study in TPC revealed that the extracts and their fractions contain various amounts of total phenolics. Therefore, the high antioxidant activity of L. martabanica may result from the presence of these compounds. Antioxidant activity study in the plant extract represents an important role. Since substances with low antioxidant activity in vitro will probably show little efficacy in vivo [39]. L. martabanica extracts and their fractions exhibited high antioxidant properties. Therefore, we selected crude water extract to investigate the antipesticide potential in rats, since this part was utilized for detoxification purposes by people in the highland community.

Chlorpyrifos was used to study the effect of $L$. martabanica on pesticide-exposed rats. The results showed a decrease in AChE activity in the chlorpyrifos-treated group. However, treatment with L. martabanica extract tended to restore AChE activity, especially at the high doses of 750 and $250 \mathrm{mg} / \mathrm{kg}$. From this result, L. martabanica extract may potentially be used as an anti-pesticide agent. Organophosphate pesticide toxicity is mainly due to AChE inhibition, which causes acetylcholine accumulation. Other mechanisms are involved in oxidative stress and free radical generation [40,41]. Oxidative stress induction by pesticides may occur in many ways [6]. The central mechanism results from the autoxidation process, which increases reactive oxygen species (ROS) production. Some pesticides can alter electron transport chains in mitochondria and endoplasmic reticulum, leading to ROS overproduction. Moreover, pesticides can also inhibit antioxidant and associated enzymes or inhibit the biosynthesis of antioxidants such as glutathione [6]. It has been reported that antioxidant enzymes, such as superoxide dismutase (SOD), catalase, and glutathione-Stransferase activities, are decreased in chlorpyrifos intoxication [42].

The flavonoids found in many plants are powerful natural substances to scavenge free radicals $[36,38]$. The antioxidant activity of flavonoids is reported to correlate with polyphenolic structures $[43,44]$. In our study, the crude water extract consists of phenolic compounds and flavonoids. Therefore, high antioxidant activities may relate to their structure. We suggest that the anti-pesticide potential of L. martabanica extract may be partly due to antioxidant properties. It has been reported that acute oral poisoning by chlorpyrifos involves AChE inhibition [45]. In this study, chlorpyrifos-exposed rats showed signs of toxicity, such as piloerection, irregular respiratory patterns, and isolation from the group. The rats treated with L. martabanica extract exhibited behavior similar to the normal group. This effect may result from the anti-pesticide potential of L. martabanica extract, which could increase AChE activity.

The hematological analysis is the sensitive indicator to assess the toxicity of the plant extract, since the ingestion of toxic compounds could change various parameters in the hematological system [46]. RBC, white blood cell (WBC), and platelets are used to assess the health of laboratory animals. RBC function involves carrying oxygen from the lungs to the body as well as bringing carbon dioxide back to the lungs. RBCs volume decreased in various conditions, including blood loss, immune-mediated hemolysis, inflammatory disease, renal disease, iron deficiency, myelodysplastic disease, genetic disorders, and neoplasia [47]. WBCs serve to eliminate foreign bodies. Therefore, WBC counts may be used to indicate infection, inflammation, and immune system disorders. PLTs are 
cells that play an important role in blood clotting. A decreased number of platelets or thrombocytopenia is associated with bleeding [47]. The MCV, MCH, and $\mathrm{MCHC}$ represent the size of RBC, the amount of hemoglobin in RBC, and the concentration of hemoglobin in an average $\mathrm{RBC}$, respectively [48]. In this study, the values of $\mathrm{MCV}, \mathrm{MCH}$, and $\mathrm{MCHC}$ increased in the pesticide-exposed rats. This effect may be compensated by increasing the RBC volume to carry the oxygen supply to the rats' bodies. Our results correlate with a previous study, in which short-term chlorpyrifos exposure caused a decrease of RBCs and $\mathrm{HCT}$ and an increase of MCV, MCH, and MCHC in rats $[49,50]$ However, abnormal hematological parameters could be normalized by treatment with L. martabanica extract.

Blood chemistry profiles were measured to assess the physiological and pathology state of vital organs of laboratory animals. The kidney function of rats was assessed by $\mathrm{BUN}$ and $\mathrm{Cr}$ measurement. The results showed a slight increase in BUN and $\mathrm{Cr}$ levels in chlorpyrifos-exposed rats. L. martabanica treatment tended to reduce BUN and Cr levels, and these values did not differ from the normal group. Release of AST, ALT, and ALP into the blood occurred after liver cells injury. Therefore, the increase in these enzymes indicated liver cell damage. Bilirubin (TB and $\mathrm{DB})$ is an indication of the detoxification function of the liver. An increase in TB and DB in the bloodstream demonstrated abnormal liver function in the detoxification of toxic substances. The levels of TP and ALB reflect the synthetic function of the liver. In chronic liver diseases, the liver loses the synthetic function, which causes a reduction in TP and ALB levels in the bloodstream. ALB also decreased in renal diseases due to loss from the glomerulus [51,52]. Chlorpyrifos-induced toxicity in rats involved in free radical generation leading to liver cell damage and increased liver enzymes [40,41]. In this study, the liver biomarkers TB, DB, AST, ALT, and ALP increased in chlorpyrifos-exposed rats. These results correlate with previous research $[40,41,53]$. L. martabanica extract treatment may protect the liver cell, as the results revealed the reduction of abnormal values of liver biomarkers. All clinical chemistry values of rats treated with the extracts comparable with those of the normal group. The results showed no aberration to indicate the presence of a physiological abnormality in the rats and the pathology of the vital organs such as the liver and kidneys. There was little difference in elevation or decline in some clinical chemistry values, which were not affected in liver and kidney function, and all values were within the reference ranges [28].

The liver histology results revealed the necrosis of hepatic cells in the chlorpyrifosexposed group with an increasing number of sinusoids dilatation. The results correlate with those previously reported by Albasher and colleagues [54]. L. martabanica extract treatment helped to protect the liver cells from damage in the rats. The histopathology results showed a reduced number of sinusoid dilation and no hepatic necrosis in the extract-treated group. The liver cells of rats in the treatment group varied in shapes and sizes and exhibited vesicles with small nuclei. These are signs of hepatic regeneration that cause the restoration of the total number and mass of hepatocytes. Loss of liver mass can be induced by toxic chemicals administration. This process is followed by an inflammatory response and a regeneration response [55]. We suggest that the L. martabanica extract may improve liver function and protect against oxidative damage induced by chlorpyrifos.

\section{Materials and Methods}

\subsection{Plant Material}

Litsea martabanica was collected from Chiang Mai province, Thailand. The plant material was identified by the taxonomist. The voucher specimen was deposited in the Queen Sirikit Botanical Garden (No. WP 7185). The roots of L. martabanica were selected, reduced in size and dried in the hot air oven until the moisture was less than $10 \%$, after which they were pulverized. The powder of the plant material was evaluated for their quality of raw material following the methods described in the Thai Herbal Pharmacopoeia 2018 [27]. 


\subsection{Extraction of L. martabanica (Root)}

The extraction process followed traditional methods. The coarse powder of the roots was extracted by decoction using water as a solvent. The extract was filtrated, concentrated until \% total soluble solid or Brix $=3$, and then dried by a spray dryer. Besides the water extract, the root of L. martabanica was extracted with $95 \%$ ethanol. The crude ethanol extract was separated by partition technique using $\mathrm{n}$-hexane and chloroform $\left(\mathrm{CHCl}_{3}\right)$, respectively. The fractions of n-hexane, $\mathrm{CHCl}_{3}$, and aqueous ethanol were evaporated and used for in vitro antioxidant activity study.

\subsection{Chemical Profile by High Performance Thin Layer Chromatography}

The extract samples $(1 \mathrm{mg})$ were separately dissolved in $1 \mathrm{~mL}$ of aqueous ethanol as a test solution. Standards (apigenin, caffeic acid, gallic acid, kaemferol, pinene, and quercetin) were each prepared in the concentration of $1 \mathrm{mg} / 1 \mathrm{~mL}$. A CAMAG (Muttenz, Switzerland) HPTLC system, comprising a Linomat 5 automatic applicator with a $10 \mathrm{~mL}$ syringe, CAMAG automatic developing Chamber 2 (ADC 2), Camag TLC scanner 4, and winCATS software version 1.4 was used. For HPTLC fingerprinting analysis, $2 \mu \mathrm{L}$ of the test solution and $2 \mu \mathrm{L}$ of the standard solution were loaded as $8 \mathrm{~mm}$ band length in the Silica Gel $\mathrm{GF}_{254}$ TLC plate. The plate was kept in TLC twin trough developing chamber (after saturated with solvent vapor) with the mobile phase (Ethyl acetate: Methanol:Water $=70: 26: 4)$. (Ethyl acetate: Methanol:Water $=70: 26: 4)$. Densitometric scanning was performed with a TLC scanner equipped with winCATS software. The plate was scanned at 254, 280, and $320 \mathrm{~nm}$. The plate was kept in a photo-documentation chamber (CAMAG TLC Visualizer 2) and captured the images at White light, UV $254 \mathrm{~nm}$, and UV $366 \mathrm{~nm}$. The developed plate was sprayed with respective spray reagents (anisaldehyde, DPPH, natural product spraying reagent) and dried at $100{ }^{\circ} \mathrm{C}$ in a hot air oven.

\subsection{DPPH Assay}

The DPPH assay was performed to evaluate the free radical scavenging activity of the extract fractions. The DPPH (2,2-diphenyl-1-picrylhydrazyl) was dissolved in methanol at a final concentration of $80 \mu \mathrm{g} / \mathrm{mL}$ [56]. The extracts were diluted in various concentrations. The assay method was done on a 96-wells plate as described by Phull and co-workers [57]. Each diluted extract $(20 \mu \mathrm{L})$ was pipetted into a separate well. Then, DPPH solution $(180 \mu \mathrm{L})$ was added and mixed. The plate was incubated at room temperature for $30 \mathrm{~min}$ in the dark. The absorbance was measured at $517 \mathrm{~nm}$ using a microplate reader. Gallic acid and methanol were used as a reference standard and control, respectively. The percentage of DPPH scavenging activity was calculated using the formula as Equation (1):

DPPH scavenging $(\%)=\frac{\text { Absorbance of control }- \text { Absorbance of test sample }}{\text { Absorbance of control }} \times 100$

The concentration of the sample required for the inhibition of 50\% of DPPH radicals was expressed as $\mathrm{IC}_{50}$ values [56]. The $\mathrm{IC}_{50}$ values were calculated using linear regression analysis and used to indicate the antioxidant capacity of the extract.

\subsection{Superoxide Radical Assay}

The assay was performed to assess the antioxidant activity of the test sample in scavenging superoxide free radicals. Phenazine methosulfate (PMS) and nicotinamide adenine dinucleotide (NADH) were used to generate superoxide free radicals in the system. Then, superoxide radicals reduced nitro blue tetrazolium (NBT) to purple formazan $[58,59]$. The reagents PMS $(25 \mu \mathrm{M}), \mathrm{NADH}(0.5 \mathrm{mM})$, and NBT $(0.2 \mathrm{mM})$ were dissolved in phosphate buffer solution ( $\mathrm{pH} 7.4)$. To perform the assay, NBT solution $(50 \mu \mathrm{L})$, NADH solution $(50 \mu \mathrm{L})$, and different concentrations of samples $(50 \mu \mathrm{L})$ were pipetted into a 96-well plate and mixed. Then, PMS solution $(50 \mu \mathrm{L})$ was added to the well. The plate was mixed and sat at room temperature for $10 \mathrm{~min}$. Then measured the $\mathrm{OD}$ at $560 \mathrm{~nm}$ using a microplate reader. Gallic acid and phosphate buffer solution were used as a reference standard and 
control, respectively. The percentage of superoxide radicals scavenging and the $\mathrm{IC}_{50}$ values were calculated by the same equation as the DPPH assay.

\subsection{2,2'-Azino-Bis-(3-Ethylbenzothiazoline-6-Sulfonic Acid) (ABTS) Assay}

ABTS radical scavenging activity of the extracts was conducted according to method described by Sharopov and co-workers [60]. The ABTS reagent was prepared by dissolving $38 \mathrm{mg}$ ABTS reagent in $10 \mathrm{~mL}$ deionized purified water (final concentration was $7.0 \mathrm{mM}$ ). Then, $6.5 \mathrm{mg}$ potassium persulfate was added to the ABTS solution and allowed to react for $16 \mathrm{~h}$ to form the stable ABTS ${ }^{\bullet+}$ radical cation. After $16 \mathrm{~h}$ of incubation, ABTS solution was diluted with distilled water to obtain a final absorbance value between $0.700 \pm 0.02$ at $630 \mathrm{~nm}$. To perform the ABTS assay, $10 \mu \mathrm{L}$ of diluted extracts were loaded into a 96-well plate, and $190 \mu \mathrm{L}$ of ABTS reagent was added to the well. The absorbance was measured at $630 \mathrm{~nm}$ after $15 \mathrm{~min}$ of mixture reaction. Trolox was used as standard substance. The results were expressed in milligram equivalents of trolox per gram of dry weight extract.

\subsection{Ferric Reducing Antioxidant Power (FRAP) Assay}

The FRAP assay was conducted according to the FRAP assay method with slight modifications [61,62]. FRAP reagent was prepared freshly by mixing $300 \mathrm{mM}$ acetate buffer pH 3.6, $10 \mathrm{mM}$ TPTZ (2,4,6-tri(2-pyridyl)-s-triazine) in $40 \mathrm{mM} \mathrm{HCl}$, and $20 \mathrm{mM} \mathrm{FeCl}_{3} \cdot 6 \mathrm{H}_{2} \mathrm{O}$ in a volume ratio 10:1:1. The FRAP working solution was warmed at $37^{\circ} \mathrm{C}$ for $30 \mathrm{~min}$ prior to the assay. For the determination of the FRAP assay, $10 \mu \mathrm{L}$ of the diluted test compound was mixed with $190 \mu \mathrm{L}$ FRAP reagent in a 96-well plate, left for $5 \mathrm{~min}$ at room temperature, and the absorbance was measured at $595 \mathrm{~nm}$ in a microplate reader [60]. Ferrous sulphate $\left(\mathrm{FeSO}_{4}\right)$ was used to generate the standard curve. FRAP values were expressed as $\mathrm{mM} \mathrm{Fe}$ (II)/g dry weight extract.

\subsection{Total Phenolics Content}

Total phenolics content of the extracts was determined using Folin-Ciocalteu method [63] with slight modifications. The test sample $(10 \mu \mathrm{L})$ of extract diluted appropriately in dimethyl sulfoxide (DMSO) was mixed with $100 \mu \mathrm{L}$ Folin-Ciocalteu's phenol reagent freshly diluted $1 / 10$ with distilled water. After five minutes of incubation, $100 \mu \mathrm{L}$ of $7.5 \% \mathrm{Na}_{2} \mathrm{CO}_{3}$ solution was added, and left for $60 \mathrm{~min}$, before measurement of absorbance at $650 \mathrm{~nm}$ in a microplate reader. Appropriate blanks (DMSO) and standard (gallic acid in DMSO) were run simultaneously. The phenolic content was calculated as gallic acid equivalents (GAE mg/g dry weight extract) on the basis of a standard curve of gallic acid [64].

\subsection{Anti-Pesticide Potential}

\subsubsection{Animals}

Male Sprague-Dawley rats, weighing 180-200 g, were detained from the National Laboratory Animal Center, Nakorn Pathom. They were housed under standard environmental conditions of temperature at $24 \pm 1{ }^{\circ} \mathrm{C}$ under a $12 \mathrm{~h}$ dark-light cycle. All animals had free access to drinking water and standard pellet diet (082 C.P. MICE FEED, S.W.T. Co., Ltd., Samut Prakan, Thailand). They were acclimatized at least one week before starting the experiments. The Animal Ethics Committee of Faculty of Medicine, Chiang Mai University approved all experimental protocols, No. 49/2559.

\subsubsection{Experimental Groups}

The anti-pesticide potential of L. martabanica water extract was modified from the method previously reported [65]. Male rats were divided into five groups of six animals each.

Group 1, normal group: rats received no treatment, only $2 \mathrm{~mL} / \mathrm{kg}$ of distilled water by gavage daily for 16 days and were used to determine the normal values of tested parameters. 
Group 2, control group: rats received $2 \mathrm{~mL} / \mathrm{kg}$ of distilled water by gavage daily for 16 days (four rounds).

Group 3, test group: rats received the cycle dose of the root water extract of L. martabanica $7.5 \mathrm{mg} / \mathrm{kg}$ for 2 days, then $2.5 \mathrm{mg} / \mathrm{kg}$ for 2 days; each rat received the extract daily for 16 days (four rounds).

Group 4, test group: rats received the cycle dose of the root water extract of L. martabanica $75 \mathrm{mg} / \mathrm{kg}$ for 2 days, then $25 \mathrm{mg} / \mathrm{kg}$ for 2 days; each rat received the extract daily for 16 days (four rounds).

Group 5, test group: rats received the cycle dose of the root water extract of L. martabanica $750 \mathrm{mg} / \mathrm{kg}$ for 2 days, then $250 \mathrm{mg} / \mathrm{kg}$ for 2 days; each rat received the extract daily for 16 days (four rounds).

The rats in group 3 to 5 received the extract in a way that mimics the traditional methods of tribal communities on the highlands. Distilled water and L. martabanica extract were orally given to the rats $30 \mathrm{~min}$ prior to receiving chlorpyrifos (Sigma) at a dose of $16 \mathrm{mg} / \mathrm{kg}$. On the 17th day, all rats were anesthetized with phenobarbital sodium (50 mg/ kg, intraperitoneally). A cannula was inserted into the common carotid artery for blood collection. A blood sample of each rat was distributed into a clean tube without anticoagulant and a tube with anticoagulant (EDTA).

\subsection{Assay of AChE Activity}

AChE activity was determined by using an $\mathrm{AChE}$ assay kit according to the assay protocols (Sigma) [66]. Briefly, whole blood samples were diluted (1:40) with assay buffer, $\mathrm{pH}$ 7.5. Then, $10 \mu \mathrm{L}$ of samples was transferred into separate wells of the 96-well plate and $190 \mathrm{~mL}$ of the working reagent were added to all samples. The reaction mixtures were mixed and incubated at room temperature. The absorbance was monitored at $2 \mathrm{~min}$ and $10 \mathrm{~min}$, respectively, by a microplate reader at $412 \mathrm{~nm}$. AChE activity was calculated using the formula as Equation (2):

$\mathrm{AChE}$ activity (units $/ \mathrm{L})=\frac{\mathrm{A}(\text { sample }) \text { at } 10 \mathrm{~min}-\mathrm{A}(\text { sample }) \text { at } 2 \mathrm{~min}}{\mathrm{~A}(\text { calibrator }) \text { at } 10 \mathrm{~min}-\mathrm{A}(\text { blank }) \text { at } 2 \mathrm{~min}} \times \mathrm{n} \times 200$

$\mathrm{A}=$ absorbance; 200 = equivalent activity (units $/ \mathrm{L}$ ) of the calibrator when assayed is read at 2 and $10 \mathrm{~min} ; \mathrm{n}=$ dilution factor

\subsection{Observation of Behavioral Change and Toxicological Signs}

Behavior change after chlorpyrifos and L. martabanica extracts administration were observed in the rats. The signs of toxicity, such as piloerection, diarrhea, tremor, lack of coordination, salivation, lacrimation, and others, were observed and recorded [65].

\subsection{Body Weight Change, Internal Organ Weight, and Histopathological Studies}

During the experiment, the rats' body weight was measured once daily. On day 17 , the rats were sacrificed and the liver removed for weighing and gross pathological detection. The liver was preserved in 10\% neutral buffered formaldehyde solution for histopathological examination.

\subsection{Hematology Analysis}

Blood samples were collected and determined, and blood count was completed using the automatic hematology system to evaluate red blood cell (RBC), white blood cell (WBC), hemoglobin (HGB), hematocrit (HCT), mean corpuscular volume (MCV), mean corpuscular hemoglobin $(\mathrm{MCH})$, mean corpuscular hemoglobin concentration (MCHC), platelet (PLT), neutrophil (Nu), lymphocyte (lymph), monocyte (Mono), eosinophil (E), and basophil (Ba). 


\subsection{Blood Chemistry Analysis}

Clotted blood samples were centrifuged to collect the serum. Blood chemistry, such as blood urea nitrogen (BUN), creatinine (Cr), total protein (TP), albumin (ALB), total bilirubin (TB), direct bilirubin (DB), aspartate aminotransferase (AST), alanine aminotransferase (ALT), and alkaline phosphatase (ALP), was analyzed.

\subsection{Statistical Analysis}

For in vitro antioxidant assays, data were presented as the mean \pm standard error of the mean (S.E.M) from three independent experiments. For in vivo experiments, statistical comparisons between the mean of each group were analyzed using the one-way ANOVA with Post Hoc multiple comparison. A value of $p<0.05$ was considered statistically significant.

\section{Conclusions}

From our results, it can be concluded that $L$. martabanica extract possesses anti-pesticide potential, which may be partly from antioxidant properties. This study provides scientific data to support the use of L. martabanica as folkloric medicines. However, the other pharmacological activities and underlying mechanisms should be studied.

Author Contributions: P.K. participated in the study designs, performed the experiments, performed data analyses and interpretation, and wrote and prepared the manuscript. S.C. prepared L. martabanica extracts and performed the chemical pattern of the extract. A.W. and P.Y. collected and identified the plant. S.S. sought funding, participated in the study designs, and performed the experiments, data analyses, and interpretation. All authors have read and agreed to the published version of the manuscript.

Funding: This research was funded by the Highland Research and Development Institute (public organization) research grant for investigation and development of medicinal and folk medicine innovation from local wisdom in highland communities.

Institutional Review Board Statement: All experiment protocols and ethical aspects were approved by The Animal Ethics Committee of Faculty of Medicine, Chiang Mai University No. 49/2559.

Informed Consent Statement: Not applicable.

Data Availability Statement: The data presented in this study are available in this article.

Conflicts of Interest: The authors declare that there is no conflict of interest.

Sample Availability: Not available.

\section{References}

1. Ngearnsaengsaruay, C.; Middleton, D.J.; Chayamarit, K. A revision of the genus Litsea Lam. (Lauraceae) in Thailand. Thai Forest Bull. Bot. 2011, 40-119.

2. Kamle, M.; Mahato, D.K.; Lee, K.E.; Bajpai, V.K.; Gajurel, P.R.; Gu, K.S.; Kumar, P. Ethnopharmacological Properties and Medicinal Uses of Litsea cubeba. Plants 2019, 8, 150. [CrossRef]

3. Wang, Y.-S.; Wen, Z.-Q.; Li, B.-T.; Zhang, H.-B.; Yang, J.-H. Ethnobotany, phytochemistry, and pharmacology of the genus Litsea: An update. J. Ethnopharmacol. 2016, 181, 66-107. [CrossRef] [PubMed]

4. Kong, D.-G.; Zhao, Y.; Li, G.-H.; Chen, B.-J.; Wang, X.-N.; Zhou, H.-L.; Lou, H.-X.; Ren, D.-M.; Shen, T. The genus Litsea in traditiona Chinese medicine: An ethnomedical, phytochemical and pharmacological review. J. Ethnopharmacol. 2015, 164, 256-264. [CrossRef] [PubMed]

5. The Highland Research and Development Institute. Local Plant Utilization Guide; The Highland Research and Development Institute (Public Organization): Chiang Mai, Thailand, 2018; p. 118.

6. Lushchak, V.I.; Matviishyn, T.M.; Husak, V.V.; Storey, J.M.; Storey, K.B. Pesticide toxicity: A mechanistic approach. EXCLI J. 2018, 17, 1101-1136. [CrossRef] [PubMed]

7. Vale, J.A.; Bradberry, S.M. Organophosphate and Carbamate Insecticide. In Critical Care Toxicology: Diagnosis and Management of the Critically Poisoned Patient; Brent, J., Burkhart, K., Dargan, P., Hatten, B., Megarbane, B., Palmer, R., White, J., Eds.; Springer: Cham, Switzerland. Available online: https:/ / doi.org/10.1007/978-3-319-17900-1_52 (accessed on 28 March 2021).

8. Colović, M.B.; Krstić, D.Z.; Lazarević-Pašti, T.D.; Bondžić, A.M.; Vasić, V.M. Acetylcholinesterase inhibitors: Pharmacology and toxicology. Curr. Neuropharmacol. 2013, 11, 315-335. [CrossRef] [PubMed] 
9. Milatovic, D.; Gupta, R.C.; Aschner, M. Anticholinesterase Toxicity and Oxidative Stress. Sci. World J. 2006, 6, 683173. [CrossRef]

10. Al-Gubory, K.H. Environmental pollutants and lifestyle factors induce oxidative stress and poor prenatal development. Reprod. Biomed. Online 2014, 29, 17-31. [CrossRef]

11. Mecdad, A.A.; Ahmed, M.H.; ElHalwagy, M.E.A.; Afify, M.M.M. A study on oxidative stress biomarkers and immunomodulatory effects of pesticides in pesticide-sprayers. Egypt. J. Forensic Sci. 2011, 1, 93-98. [CrossRef]

12. Soltaninejad, K.; Abdollahi, M. Current opinion on the science of organophosphate pesticides and toxic stress: A systematic review. Med. Sci. Monit. 2009, 15, Ra75-Ra90.

13. Akhgari, M.; Abdollahi, M.; Kebryaeezadeh, A.; Hosseini, R.; Sabzevari, O. Biochemical evidence for free radical-induced lipid peroxidation as a mechanism for subchronic toxicity of malathion in blood and liver of rats. Hum. Exp. Toxicol. 2003, 22, 205-211. [CrossRef] [PubMed]

14. Abdollahi, M.; Ranjbar, A.; Shadnia, S.; Nikfar, S.; Rezaie, A. Pesticides and oxidative stress: A review. Med. Sci. Monit. 2004, 10, Ra141-Ra147. [PubMed]

15. Weichenthal, S.; Moase, C.; Chan, P. A review of pesticide exposure and cancer incidence in the Agricultural Health Study cohort. Environ. Health. Perspect. 2010, 118, 1117-1125. [CrossRef] [PubMed]

16. Al-Eryani, L.; Wahlang, B.; Falkner, K.C.; Guardiola, J.J.; Clair, H.B.; Prough, R.A.; Cave, M. Identification of Environmental Chemicals Associated with the Development of Toxicant-associated Fatty Liver Disease in Rodents. Toxicol. Pathol. 2015, 43, 482-497. [CrossRef] [PubMed]

17. Leikin, J.B.; Davis, A.; Klodd, D.A.; Thunder, T.; Kelafant, G.A.; Paquette, D.L.; Rothe, M.J.; Rubin, R. Part IV. Occupational liver disease. Dis. Mon. 2000, 46, 295-310. [CrossRef]

18. Ranjbar, A.; Solhi, H.; Mashayekhi, F.J.; Susanabdi, A.; Rezaie, A.; Abdollahi, M. Oxidative stress in acute human poisoning with organophosphorus insecticides; a case control study. Environ. Toxicol. Pharmacol. 2005, 20, 88-91. [CrossRef]

19. Nurulain, S.M.; Szegi, P.; Tekes, K.; Naqvi, S.N. Antioxidants in organophosphorus compounds poisoning. Arh. Hig. Rada. Toksikol. 2013, 64, 169-177. [CrossRef]

20. Sies, H. Oxidative stress: From basic research to clinical application. Am. J. Med. 1991, 91, 31S-38S. [CrossRef] [PubMed]

21. Pisoschi, A.M.; Pop, A.; Cimpeanu, C.; Predoi, G. Antioxidant Capacity Determination in Plants and Plant-Derived Products: A Review. Oxidative Med. Cell. Longev. 2016, 2016, 9130976. [CrossRef]

22. Kasote, D.M.; Katyare, S.S.; Hegde, M.V.; Bae, H. Significance of antioxidant potential of plants and its relevance to therapeutic applications. Int. J. Biol. Sci. 2015, 11, 982-991. [CrossRef]

23. Jalili, C.; Farzaei, M.; Roshankhah, S.; Salahshoor, M. Resveratrol attenuates malathion-induced liver damage by reducing oxidative stress. J. Lab. Physicians. 2019, 11, 212-219. [CrossRef]

24. Lobo, V.; Patil, A.; Phatak, A.; Chandra, N. Free radicals, antioxidants and functional foods: Impact on human health. Pharmacogn. Rev. 2010, 4, 118-126. [CrossRef]

25. Eroğlu, S.; Pandir, D.; Uzun, F.G.; Bas, H. Protective role of vitamins C and E in dichlorvos-induced oxidative stress in human erythrocytes in vitro. Biol. Res. 2013, 46, 33-38. [CrossRef] [PubMed]

26. Ambali, S.F.; Idris, S.B.; Onukak, C.; Shittu, M.u.; Ayo, J.O. Ameliorative effects of vitamin C on short-term sensorimotor and cognitive changes induced by acute chlorpyrifos exposure in Wistar rats. Toxicol. Ind. Health. 2010, 26, 547-558. [CrossRef] [PubMed]

27. Department of Medical Sciences, Ministry of Public Health, Thailand. THP; Office of Notional Buddishm Press: Bangkok, Thailand, 2018.

28. He, Q.; Su, G.; Liu, K.; Zhang, F.; Jiang, Y.; Gao, J.; Liu, L.; Jiang, Z.; Jin, M.; Xie, H. Sex-specific reference intervals of hematologic and biochemical analytes in Sprague-Dawley rats using the nonparametric rank percentile method. PLoS ONE 2017, 12, e0189837. [CrossRef] [PubMed]

29. Dudonné, S.; Vitrac, X.; Coutière, P.; Woillez, M.; Mérillon, J.M. Comparative study of antioxidant properties and total phenolic content of 30 plant extracts of industrial interest using DPPH, ABTS, FRAP, SOD, and ORAC assays. J. Agric. Food Chem. 2009, 57, 1768-1774. [CrossRef] [PubMed]

30. Kahkonen, M.P.; Hopia, A.I.; Vuorela, H.J.; Rauha, J.P.; Pihlaja, K.; Kujala, T.S.; Heinonen, M. Antioxidant activity of plant extracts containing phenolic compounds. J. Agric. Food. Chem. 1999, 47, 3954-3962. [CrossRef] [PubMed]

31. Nimse, S.B.; Pal, D. Free radicals, natural antioxidants, and their reaction mechanisms. RSC Adv. 2015, 5, 27986-28006. [CrossRef]

32. Yuan, M.; Jia, X.; Ding, C.; Yuan, S.; Zhang, Z.; Chen, Y. Comparative Studies on Bioactive Constituents in Hawk Tea Infusions with Different Maturity Degree and Their Antioxidant Activities. Sci. World J. 2014, 2014, 838165. [CrossRef]

33. Hwang, J.-K.; Choi, E.-M.; Lee, J.H. Antioxidant activity of Litsea cubeba. Fitoterapia 2005, 76, 684-686. [CrossRef] [PubMed]

34. Agrawal, N.; Choudhary, A.S.; Sharma, M.C.; Dobhal, M.P. Chemical Constituents of Plants from the Genus Litsea. Chem. Biodivers. 2011, 8, 223-243. [CrossRef] [PubMed]

35. Rahman, M.M.; Islam, M.B.; Biswas, M.; Khurshid Alam, A.H.M. In vitro antioxidant and free radical scavenging activity of different parts of Tabebuia pallida growing in Bangladesh. BMC Res. Notes. 2015, 8, 621. [CrossRef]

36. Rice-Evans, C.; Miller, N.; Paganga, G. Antioxidant properties of phenolic compounds. Trends Plant Sci. 1997, 2, 152-159. [CrossRef]

37. Pourreza, N. Phenolic compounds as potential antioxidant. Jundishapur J. Nat. Pharm. Prod. 2013, 8, 149-150. [CrossRef] 
38. Rice-Evans, C.A.; Miller, N.J.; Paganga, G. Structure-antioxidant activity relationships of flavonoids and phenolic acids. Free Radic. Biol. Med. 1996, 20, 933-956. [CrossRef]

39. Nunes, X.P.; Silva, F.S.; Almeida, J.R.G.D.S.; Barbosa Filho, J.M.; de Lima, J.T.; de Araújo Ribeiro, L.A.; Júnior, L.J.Q. Biological Oxidations and Antioxidant Activity of Natural Products. In Phytochemicals as Nutraceuticals-Global Approaches to Their Role in Nutrition and Health; Rao, V., Ed.; InTech: Shangai, China, 2012; pp. 1-20. [CrossRef]

40. Singh, N.; Lawana, V.; Luo, J.; Phong, P.; Abdalla, A.; Palanisamy, B.; Rokad, D.; Sarkar, S.; Jin, H.; Anantharam, V.; et al. Organophosphate pesticide chlorpyrifos impairs STAT1 signaling to induce dopaminergic neurotoxicity: Implications for mitochondria mediated oxidative stress signaling events. Neurobiol. Dis. 2018, 117, 82-113. [CrossRef]

41. Rahal, A.; Kumar, A.; Singh, V.; Yadav, B.; Tiwari, R.; Chakraborty, S.; Dhama, K. Oxidative stress, prooxidants, and antioxidants: The interplay. Biomed Res. Int. 2014, 2014, 761264. [CrossRef]

42. Wellington, K.; Jarvis, B. Silymarin: A Review of its Clinical Properties in the Management of Hepatic Disorders. BioDrugs 2001, 15, 465-489. [CrossRef]

43. Panche, A.N.; Diwan, A.D.; Chandra, S.R. Flavonoids: An overview. J. Nutr. Sci. 2016, 5, e47. [CrossRef] [PubMed]

44. Permender, R.; Hema, C.; Sushila, R.; Dharmender, R.; Vikash Kumar and Kanchan, K. Mechanism of Action of Flavonoids as Anti-inflammatory Agents: A Review. Inflamm. Allergy Drug Targets. 2009, 8, 229-235. [CrossRef]

45. Clegg, D.J.; van Gemert, M. Determination of the reference dose for chlorpyrifos: Proceedings of an expert panel. J. Toxicol. Environ. Health. B Crit. Rev. 1999, 2, 211-255. [CrossRef] [PubMed]

46. Adeneye, A.A.; Ajagbonna, O.P.; Adeleke, T.I.; Bello, S.O. Preliminary toxicity and phytochemical studies of the stem bark aqueous extract of Musanga cecropioides in rats. J. Ethnopharmacol. 2006, 105, 374-379. [CrossRef]

47. O'Connell, K.E.; Mikkola, A.M.; Stepanek, A.M.; Vernet, A.; Hall, C.D.; Sun, C.C.; Yildirim, E.; Staropoli, J.F.; Lee, J.T.; Brown, D.E. Practical murine hematopathology: A comparative review and implications for research. Comp. Med. 2015, 65, 96-113. [PubMed]

48. Mary Anna, T.; Glade, W.; Robin, A.; Terry, C. Veterinary Hematology and Clinical Chemistry, 2nd ed.; Wiley-Blackwell: Hoboken, NJ, USA, 2012; pp. 61-401.

49. Kazmi, F.; Shakoori, A.; Hafeez, M.A.; Ali, S. Short term effects of chlorpyrifos on hematology and biochemical components of blood of the Sprague-Dawley rat. Pak. J. Zool. 2003, 35, 237-243.

50. El-Deeb, A.E.A.; Abd El-Aleem, I.M.; Sherin, S.G. Harmful effect of some insecticides on vital parameters of albino rats. J. Egypt. Soc. Toxicol. 2007, 36, 53-60.

51. Rifai, N.; Horvath, A.R.; Wittwer, C. Tietz Textbook of Clinical Chemistry and Molecular Diagnostics, 6th ed.; Elsevier: St. Louis, MO, USA, 2018; pp. 1348-1397.

52. Bishop, M.L.; Fody, E.P.; Schoeff, L.E. Clinical Chemistry: Principles, Techniques, and Correlations, 7th ed.; Wolters Kluwer Health/Hippincott Williams \& Wilkins: Philadelphia, PA, USA, 2013; pp. 260-297.

53. Al-Attar, A.M.; Elnaggar, M.H.R.; Almalki, E.A. Protective effect of some plant oils on diazinon induced hepatorenal toxicity in male rats. Saudi J. Biol. Sci. 2017, 24, 1162-1171. [CrossRef]

54. Albasher, G.; Almeer, R.; Al-Otibi, F.O.; Al-Kubaisi, N.; Mahmoud, A.M. Ameliorative Effect of Beta vulgaris Root Extract on Chlorpyrifos-Induced Oxidative Stress, Inflammation and Liver Injury in Rats. Biomolecules 2019, 9, 261. [CrossRef] [PubMed]

55. Michalopoulos, G.K. Liver regeneration. J. Cell. Physiol. 2007, 213, 286-300. [CrossRef]

56. Lee, K.J.; Oh, Y.C.; Cho, W.K.; Ma, J.Y. Antioxidant and Anti-Inflammatory Activity Determination of One Hundred Kinds of Pure Chemical Compounds Using Offline and Online Screening HPLC Assay. Evid. Based Complement. Alternat. Med. 2015, 2015, 165457. [CrossRef]

57. Phull, A.-R.; Abbas, Q.; Ali, A.; Raza, H.; Kim, S.J.; Zia, M.; Haq, I.-u. Antioxidant, cytotoxic and antimicrobial activities of green synthesized silver nanoparticles from crude extract of Bergenia ciliata. Future J. Pharm. Sci. 2016, 2, 31-36. [CrossRef]

58. Jing, L.; Ma, H.; Fan, P.; Gao, R.; Jia, Z. Antioxidant potential, total phenolic and total flavonoid contents of Rhododendron anthopogonoides and its protective effect on hypoxia-induced injury in PC12 cells. BMC Complement. Altern. Med. 2015, 15, 287. [CrossRef] [PubMed]

59. Bajpai, V.K.; Agrawal, P.; Bang, B.H.; Park, Y.-H. Phytochemical analysis, antioxidant and antilipid peroxidation effects of a medicinal plant, Adhatoda vasica. Front. Life Sci. 2015, 8, 305-312. [CrossRef]

60. Sharopov, F.S.; Wink, M.; Setzer, W.N. Radical scavenging and antioxidant activities of essential oil components-an experimental and computational investigation. Nat. Prod. Commun. 2015, 10, 153-156. [CrossRef] [PubMed]

61. Bolanos de la Torre, A.A.; Henderson, T.; Nigam, P.S.; Owusu-Apenten, R.K. A universally calibrated microplate ferric reducing antioxidant power (FRAP) assay for foods and applications to Manuka honey. Food. Chem. 2015, 174, 119-123. [CrossRef] [PubMed]

62. Benzie, I.F.F.; Strain, J.J. The Ferric Reducing Ability of Plasma (FRAP) as a Measure of "Antioxidant Power": The FRAP Assay. Anal. Biochem. 1996, 239, 70-76. [CrossRef]

63. Singleton, V.L.; Rossi, J.A. Colorimetry of Total Phenolics with Phosphomolybdic-Phosphotungstic Acid Reagents. Am. J. Enol. Vitic. 1965, 16, 144-158.

64. Clarke, G.; Ting, K.N.; Wiart, C.; Fry, J. High Correlation of 2,2-diphenyl-1-picrylhydrazyl (DPPH) Radical Scavenging, Ferric Reducing Activity Potential and Total Phenolics Content Indicates Redundancy in Use of All Three Assays to Screen for Antioxidant Activity of Extracts of Plants from the Malaysian Rainforest. Antioxidants 2013, 2, 1-10. [CrossRef] 
65. Abd-El-hameed, S.Y.; Mohamed, A.A.; Thabet, H.Z. Potential Ameliorative Role Of Silymarin Against Methyl Parathion-Induced Oxidative Stress And Hepato-Renal Toxicity In Albino Rats. MJFMCT 2009, 17, 15-40. [CrossRef]

66. Ellman, G.L.; Courtney, K.D.; Andres, V., Jr.; Feather-Stone, R.M. A new and rapid colorimetric determination of acetylcholinesterase activity. Biochem. Pharmacol. 1961, 7, 88-95. [CrossRef] 